\title{
Large-Scale Patterns of Soil Nematodes across Grasslands on the Tibetan Plateau: Relationships with Climate, Soil and Plants
}

\author{
Han Chen ${ }^{1} @$, Shuaiwei Luo ${ }^{1}$, Guixin Li ${ }^{1}$, Wanyanhan Jiang ${ }^{2,3}$, Wei $\mathrm{Qi}^{1}{ }^{1}$, Jing $\mathrm{Hu}^{4}$, Miaojun $\mathrm{Ma}{ }^{1, *}$ and \\ Guozhen Du ${ }^{1, *}$
}

check for

updates

Citation: Chen, H.; Luo, S.; Li, G.; Jiang, W.; Qi, W.; Hu, J.; Ma, M.; Du, G. Large-Scale Patterns of Soil

Nematodes across Grasslands on the Tibetan Plateau: Relationships with Climate, Soil and Plants. Diversity 2021, 13, 369. https://doi.org/ $10.3390 / \mathrm{d} 13080369$

Academic Editor: Luc Legal

Received: 8 July 2021

Accepted: 4 August 2021

Published: 9 August 2021

Publisher's Note: MDPI stays neutral with regard to jurisdictional claims in published maps and institutional affiliations.

Copyright: (c) 2021 by the authors. Licensee MDPI, Basel, Switzerland. This article is an open access article distributed under the terms and conditions of the Creative Commons Attribution (CC BY) license (https:// creativecommons.org/licenses/by/ $4.0 /)$.
1 State Key Laboratory of Grasslands and Agro-Ecosystems, School of Life Sciences, Lanzhou University, Lanzhou 730000, China; chenh16@lzu.edu.cn (H.C.); luoshw16@lzu.edu.cn (S.L.); ligx17@lzu.edu.cn (G.L.); qiw@lzu.edu.cn (W.Q.)

2 School of Public Health, Chengdu University of Traditional Chinese Medicine, Chengdu 610000, China; jiangwyh14@gmail.com

3 Key Laboratory for Environmental Pollution Prediction and Control, Gansu Province, College of Earth and Environmental Sciences, Lanzhou University, Lanzhou 730000, China

4 College of Forestry \& Life Science, Chongqing University of Arts \& Sciences, Chongqing 402160, China; 9986hujing@163.com

* Correspondence: mjma@lzu.edu.cn (M.M.); guozdu@lzu.edu.cn (G.D.); Tel.: +86-13919361389 (M.M.); +86-13519663570 (G.D.)

\begin{abstract}
Soil nematodes are important contributors to soil biodiversity. Nonetheless, the distribution patterns and environmental drivers of soil nematode communities are poorly understood, especially at the large scale, where multiple environmental variables covary. We collected 520 soil samples from 104 sites representing alpine meadow and steppe ecosystems. First, we explored the soil nematode community characteristics and compared community patterns between the ecosystems. Then, we examined the contributions of aboveground and belowground factors on these patterns. The genus richness and abundance of nematodes on the Tibetan Plateau are lower than other alpine ecosystems, but are comparable to desert or polar ecosystems. Alpine meadows supported a higher nematode abundance and genus richness than alpine steppes; bacterial-based energy channels were pre-dominant in both the ecosystems. Soil factors explained the most variation in the soil nematode community composition in the alpine meadows, while plant factors were as essential as soil factors in the alpine steppes. Unexpectedly, the climate variables barely impacted the nematode communities. This is the first study to explore the spatial patterns of soil nematode compositions on the Tibetan Plateau, and we found that the contributions of climate, plants, and soil properties on soil nematodes community were essentially different from the previous knowledge for well-studied plant and animal communities.
\end{abstract}

Keywords: alpine meadow; alpine steppe; biotic and abiotic factors; distribution patterns; environmental factors; soil biodiversity

\section{Introduction}

Soil nematodes are the most abundant multicellular animals on Earth [1], compared with soil microbes, soil nematodes occupy a wider range of trophic levels, including the plant-parasitic, predatory, and microbial feeding levels [2,3]. The community compositions of bacterial-feeding, fungal-feeding and herbivorous nematodes are determined by the variation in food resources [4-6]. As such, soil nematodes are valuable indicators of the soil food web structure [7]. Particularly, with the development of indices that describe the functional diversity of the nematode communities, such as the structure index (SI), channel index (CI), and enrichment index (EI) [7], nematode communities are broadly used to describe decomposition pathways [8,9]. Studies on soil nematode communities can potentially offer a holistic measure of the biotic and functional status of soils [10]. However, knowledge of the large-scale spatial patterns of nematode communities, and the 
mechanisms underlying these patterns, remains limited [11,12], as is the exploration of the functional diversity of soil nematodes in relation to environmental factors [13,14].

Current evidence indicates that the spatial patterns of soil nematodes may be highly ecosystem-dependent $[15,16]$. The soil nematode community is controlled by bottom-up forces via the plant community $[17,18]$, edaphic properties [19,20], and the climate [21]. At the global scale, variations in the composition of soil nematodes are mainly related to the mean annual precipitation and temperature [12]. In a recent study, van den Hoogen et al. [22] found that soil resource availability was a dominant factor in building belowground communities at broad spatial scales, and overrode the effects of climatic factors at such scales. At the regional scale, on the Mongolian Plateau, the total density of soil nematodes increased from the desert to meadow steppe, due to increases in all the nematode trophic groups. In contrast, the ratio of bacterial-feeding to fungal-feeding nematode densities decreased gradually. Such results indicated that nutrient-rich ecosystems (i.e., meadow steppe) supported richer and more complex soil nematode communities than more nutrientpoor ecosystems (i.e., steppe and desert), and the organic matter decomposition pathway shifts from bacterial-based to fungal-based channels [16]. Along the Chinese coast, $\mathrm{Wu}$ et al. [23] found that the mean annual temperature range and the $\mathrm{pH}$ of sediments were more important than the vegetation type, in structuring nematode communities. Traunspurger et al. [24] found the litter $\mathrm{C} / \mathrm{N}$ ratio and fungal biomass to be major drivers of the changes in nematode community composition in a tropical montane rainforest of Ecuador. Briefly, regional-scale changes in soil resource, plant conditions, and climate, may be the main factors to explain the variations in soil nematode diversities, but functional and species diversity respond differently, or even oppositely, to biotic and abiotic drivers [9,25]. The relative contribution of environmental factors, which overlay each other, to the largescale spatial distribution pattern of the diversity and functional diversity of soil nematodes, is still understudied [26-28].

On the Tibetan Plateau, alpine steppes and meadows are the most dominant ecosystems, occupying $44.64 \%$ and $28.75 \%$ of the total area, respectively [29,30], and reflect variations in moisture regime, soil properties, and plant seed density [31,32]. In particular, the availability of resources varies greatly between ecosystems [33-35]. It has been broadly documented that fungal energy channels are generally associated with lower nutrient availability and slower plant growth rates, compared with bacterial energy channels [36,37]. However, no study was associated with soil nematodes, to evaluate the characteristics of organic matter decomposition pathways in the soil food web on the Tibetan Plateau. Previous studies found that climatic factors largely determined the pattern and development of various biomes on the Tibetan Plateau [38-41], especially that precipitation could significantly change the water and substrate availability [41,42]. While, only a few studies have determined the diversity and distribution patterns of soil nematodes on the Tibetan Plateau [43]. The identification of the factors that control the spatial patterns of communities is a principal goal for studies on community ecology [16,44].

In this study, we explored the spatial patterns of soil nematodes, in terms of abundance and diversity as well as the characteristics of the soil food web in alpine meadow and steppe. We also examined the correlations and relative importance of the aboveground vegetation, soil properties, and the climatic factors, in relation to the soil nematode community. We hypothesized that (1) the diversity and abundance of soil nematodes would be greater in alpine meadows than in alpine steppes, and the fungal-based energy channel in the alpine steppes would shift to a bacterial-based energy channel in the alpine meadows; and (2) climate variables, especially precipitation, would determine the community of soil nematodes.

\section{Materials and Methods}

\subsection{Sampling Locations}

Sampling was conducted at 104 sites covering latitudes from $29.14^{\circ} \mathrm{N}$ to $38.85^{\circ} \mathrm{N}$, longitudes from $88.15^{\circ} \mathrm{E}$ to $101.51^{\circ} \mathrm{E}$, and elevations from $2793 \mathrm{~m}$ to $5217 \mathrm{~m}$ during 
the summer (July to August) of 2015 (from the northeastern part to the southern part of the Tibetan Plateau) and 2016 (the southeastern part and central part of the Tibetan Plateau) (Figure 1, Table S1). The mean annual precipitation in this area ranged from 211 to $749 \mathrm{~mm}$, and the mean annual temperature ranged from -8.1 to $1.9^{\circ} \mathrm{C}$. The 104 sampling sites were of the following two major ecosystems: 72 alpine meadows and 32 alpine steppes. Perennial tussock grasses, including Kobresia pygmaea and Kobresia tibetica, were dominant in the alpine meadows, whereas short and dense tussock grasses, such as Stipa purpurea, were dominant in the alpine steppes [45]. All sample sites were representative of typical vegetation at each ecosystem, and they had moderate grazing disturbance for centuries [32,46]. No significant differences of mean annual precipitation and temperature at the sample sites between 2015 and 2016 have been found (Wilcoxon signed ${ }^{-}$rank test: $p=0.067, p=0.148)$.

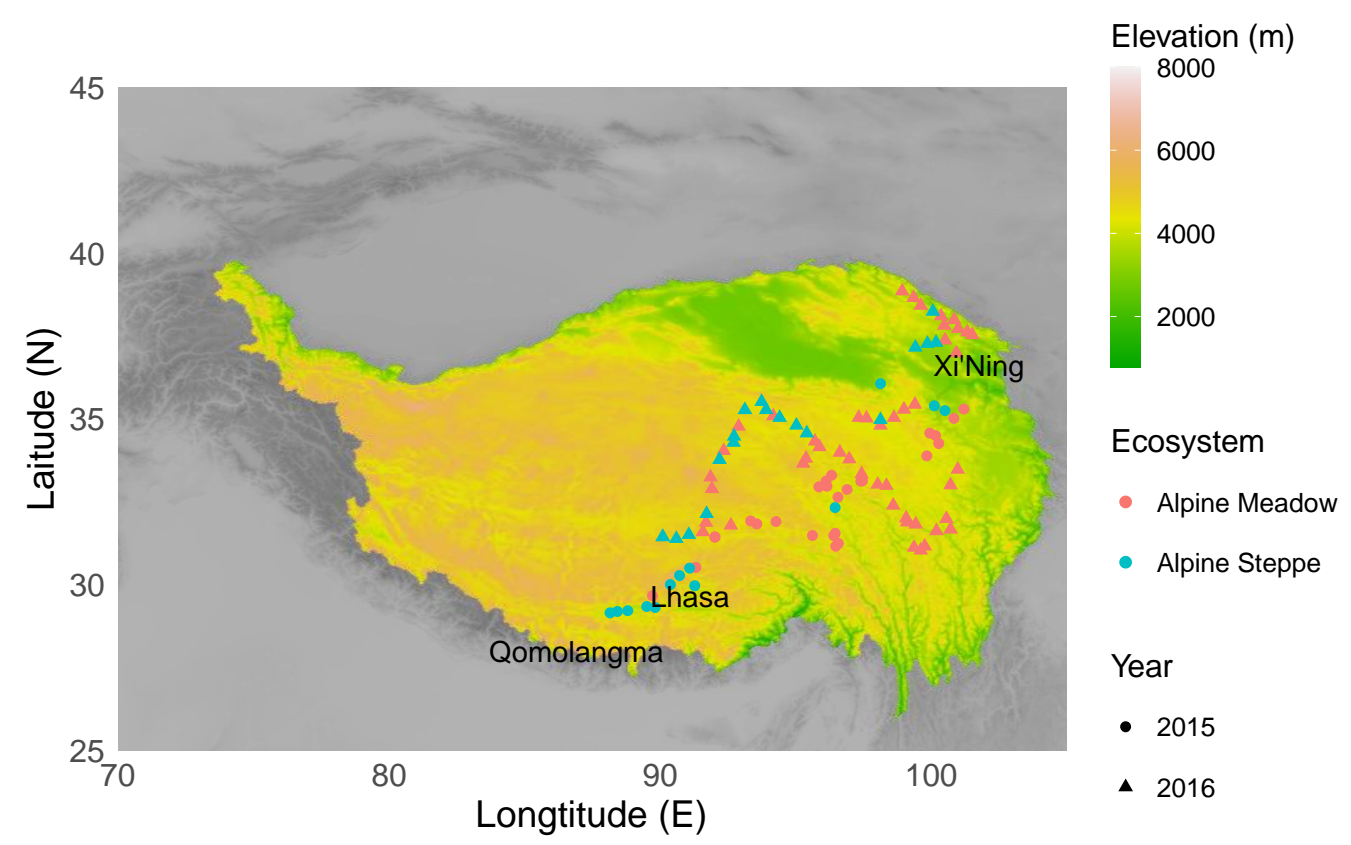

Figure 1. Sampling locations of nematode communities along geographic gradients on the Tibetan Plateau.

\subsection{Aboveground Plant and Soil Sampling}

Five plots were selected at each sampling site; the distance between two adjacent plots was $50 \mathrm{~m}$, and all plants within each plot $(1 \mathrm{~m} \times 1 \mathrm{~m})$ were identified to species level. For each plot, live aboveground biomass was clipped by species at ground level, and all plant materials were weighed. Aboveground biomass of shrubs was measured by collecting living leaves and current-year twigs of each species. Plant coverage was calculated as the ratio of the area shaded by specific species to the total area of a plot.

Soil property sampling was conducted in the same plots as the plant sampling. Five cylindrical soil cores ( $3.8 \mathrm{~cm}$ diameter) were taken at a depth of $0-20 \mathrm{~cm}$ at five locations in each plot. The five soil cores were combined to form one composite sample. Then, the composite sample was divided into two duplicates to measure soil physiochemical properties and to assess the soil nematode community. In total, 520 soil samples and an equal number of plant samples were collected from 104 sites. Five plots within one site were measured separately, and each plot was considered as a replicate $[47,48]$.

\subsection{Nematode Extraction and Identification}

The composite soil samples were stored at $4{ }^{\circ} \mathrm{C}$ and transported to Lanzhou University, China, for nematode extraction within 7 days. For nematode extraction, each soil sample was mixed by hand after removing gravel and plant residues, and $50 \mathrm{~g}$ of soil 
was randomly selected as a subsample. Nematodes were extracted by a Baermann wet funnel for $48 \mathrm{~h}$ [49]. All nematodes were identified to genus level [50-52]. When more than 150 individuals were obtained, only the first 150 individuals were identified [50,51]. Nematodes were classified into five trophic groups, namely, plant parasites, fungivores, bacterivores, predators and omnivores, to describe the functional characterization [2]. Detailed taxonomy identifications are presented in Table S2. To characterize the ecology as well as the functionality of soil nematode communities, enrichment index (EI), structure index (SI) and channel index (CI) were calculated to demonstrate the contributions and responses of nematodes to various ecosystem services and functions [7]. Additionally, to compare the differences in biodiversity of soil nematode between alpine meadows and steppes, the Rényi diversity was applied [53,54]. Moreover, the scales of Rényi diversity were set as $0,0.25,0.5,1,2,4,8$ and infinity. Detailed ecological index definitions and equations are presented in the nematode analyses section of the Supplementary Material.

\subsection{Measurement of Soil Physicochemical Properties}

Soil subsamples of $50 \mathrm{~g}$ each were dried for $72 \mathrm{~h}$ at $105^{\circ} \mathrm{C}$ to measure moisture (MOI) [55]. The remaining soil was air dried, avoiding direct sunlight, and then sieved through a 100 mesh $(0.15 \mathrm{~mm})$ to remove gravel and plant residues. Soil $\mathrm{pH}$ was measured by using a pH meter (PHSJ-3F, Shanghai INESA Scientific Instrument Co., Ltd., Shanghai, China) in a 1:2.5 soil:deionized water slurry. Soil organic carbon (SOC) was measured by wet oxidation [56]. Soil available phosphorus (AP) was extracted by the Bray method [57]. Soil total nitrogen (TN) and phosphorus (TP) were digested by concentrated $\mathrm{H}_{2} \mathrm{SO}_{4}$ at $375{ }^{\circ} \mathrm{C}$ for $3 \mathrm{~h}$ and $45 \mathrm{~min}$, respectively, followed by semi-micro-Kjeldahl and Mo-Sb antispectrophotometry [58] performed using an autochemistry analyzer (SmartChem 200, AMS Alliance, Rome Italy). $\mathrm{NH}_{4}^{+}-\mathrm{N}\left(\mathrm{NH}_{4}\right)$ and $\mathrm{NO}_{3}^{-}-\mathrm{N}\left(\mathrm{NO}_{3}\right)$ were extracted with $2 \mathrm{M}$ $\mathrm{KCl}$ and detected using a San ${ }^{++}$continuous flow analyzer (Skalar, Breda, The Netherlands).

\subsection{High-Resolution Gridded Dataset of Temperature and Precipitation}

The climate data, including the mean annual temperature (MAT) and mean annual precipitation (MAP), were obtained from a gridded dataset, the University of Delaware Air Temperature \& Precipitation dataset, version 5.01 [59]. It mainly compiled data from stations from the $\mathrm{GHCN}_{2}$ (Global Historical Climate Network) from 1900 to 2017 as well as collections of rain gauge data from a range of different data sets such as the Legates and Willmott [60] archive for station climatology. Depending on the time period, up to 22,000 rain gauges were used for the construction of UDEL. Air temperature data were interpolated by a combination of digital elevation model-assisted interpolation [61], traditional interpolation [62] and climatologically aided interpolation [61]; precipitation data were interpolated by climatologically aided interpolation [63]. This dataset has been evaluated in multiple regions of the globe [64,65], including the regions adjacent to this study [66], and the results from these studies showed that these datasets correctly recognized regimes of precipitation and temperature.

\subsection{Data Analyses}

All statistical analyses were performed with R software, version 3.6.1 (R Core Team, 2019). All figures were created using the vegan package version 2.5-3 [67] and ggplot2 package version 3.1.0.9000 [68].

We used Wilcoxon rank-sum tests with original data to compare the differences in taxonomic diversity (abundance, genus richness), trophic groups (plant parasites, fungivores, bacterivores, predators and omnivores), soil food web characteristics (SI, EI, CI), aboveground plants (plant species richness, plant biomass and plant coverage), soil properties (soil $\mathrm{pH}$, soil moisture, total nitrogen, total phosphorus, available phosphorus, ammonium, nitrate and SOC) and climatic factors (MAT and MAP) between alpine meadow and alpine steppe ecosystems because neither the original data of these factors nor the transformed data met a normal distribution. To compare the significance of the relative 
abundance of trophic groups within ecosystems, post hoc comparisons were performed using Dwass-Steel-Critchlow-Fligner procedure [69,70]. To compare the difference of the Rényi diversity between ecosystems, we displayed the diversity values against each scale in each ecosystem. Ecosystem of which Rényi diversities in all scales were higher supported higher biodiversity [53].

To explore the relationship between each environmental factor (soil moisture, $\mathrm{pH}$, total nitrogen, total phosphorus, available phosphorus, ammonium, nitrate, SOC, plant species richness, plant biomass, plant coverage, mean annual temperature and mean annual precipitation) and soil nematode genus composition and trophic composition, we performed partial redundancy analyses (pRDA), in which the sample site was set as condition variable to eliminate the dependence of climate factors on it [71-73]. To identify the most parsimonious set of variables by including only those variables with a significance level of $p<0.05$, stepwise ordinations with backward selection with Monte Carlo permutations (9999 permutations) were applied. The final pRDA models were then validated by testing the significance of the axes with significant eigenvalues using Monte Carlo permutations (9999 permutations). Based on the final pRDA models, we further performed variation partitioning analyses to assess the relative effects of each set of biotic and abiotic variables on nematode genus composition and trophic composition for each ecosystem. Variation partitioning is a method based on constrained ordination method [71,74]. To assess the partitions explained by each variable set, adjusted R-squared was used because this is the only unbiased method [74]. Due to the contributions of climate not being observed from RDA analyses, only the soil properties (i.e., soil $\mathrm{pH}$, soil moisture, total nitrogen, total phosphorus, available phosphorus, ammonium, nitrate, SOC) and plants (plant species richness, plant biomass, plant coverage), which were selected by the final RDA models, were contained to each set of variables, with detailed containing variables being shown in Tables S4 and S5. The pRDA and variation partitioning were performed by the rda function and varpart function, respectively, from vegan package version 2.5-3 [67].

To evaluate the relative importance and effects of each abiotic and biotic variable on soil nematode abundance, genus richness, and other nematode ecological indices, multiple linear regression analyses (backward elimination) were performed in each ecosystem, respectively. The Akaike information criterion (AIC) was used for model selection. Only environmental factors that were selected by the final RDA models were used to build models. As we built two RDA models for each ecosystem, one based on genus and one based on trophic groups, a complementary set of the selected environmental variables in each ecosystem was included. Therefore, $\mathrm{pH}$, soil moisture, total nitrogen, total phosphorus, ammonium and plant coverage were used to build models in alpine meadows; $\mathrm{pH}$, soil moisture, ammonium, nitrate, plant biomass, plant species richness and plant coverage were selected to build models in alpine steppe. To eliminate the effect of dimensions, z-scores were applied to standardize all variables. The individual predictor's contribution was its relative contribution to the $\mathrm{r}^{2}$ with the consideration of the sequence of predictors appearing in each model [75]. Abiotic and biotic variables were separated into the variable sets of soil properties (i.e., soil $\mathrm{pH}$, soil moisture, total nitrogen, total phosphorus, available phosphorus, nitrate) and plants (plant species richness, plant biomass, plant coverage), and only the predictors that were selected by backward procedure were contained. The detailed contained variables in each variable set are listed in Tables S6 and S7. The procedures were calculated by the calc.relimp function from relaimpo package version 2.2-3 [76].

In order to estimate the relationships between the climate factors and soil moisture, a linear mixed model was performed between mean annual precipitation/temperature and soil moisture in each ecosystem, in which the sample was set as random effect to eliminate the dependence of climate factors on it [77]. 


\section{Results}

\subsection{Soil Nematode Community in the Alpine Ecosystem on the Tibetan Plateau}

The soil nematode communities that were sampled at the 520 plots, comprised 54 genera and 7 additional families when the identification of the genus was uncertain. Both the abundance and genus richness of the soil nematodes $(p<0.001, p<0.001)$, as well as the relative abundance of plant parasites and predators $(p=0.019, p<0.001)$, were higher in the alpine meadow than in the alpine steppe (Figure 2a, Table S3). Additionally, bacterivores were the most abundant members in both the ecosystems. In contrast, predators were the least abundant (Figure 2b, Table S3). No significant differences in the SI, EI, or CI were observed between the two ecosystems (Figure 2a, Table S3). However, the values for these indices were lower than 50 in both ecosystems, indicating that the bacterial decomposition channel played more important roles than the fungal decomposition channel $[7,78]$.
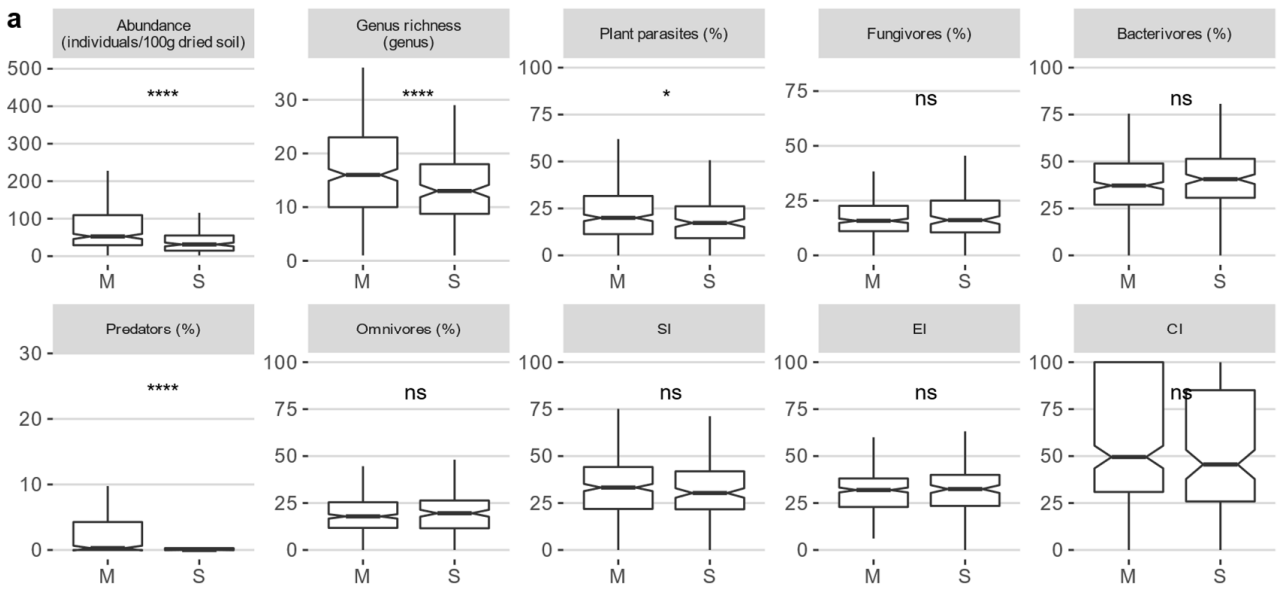

b
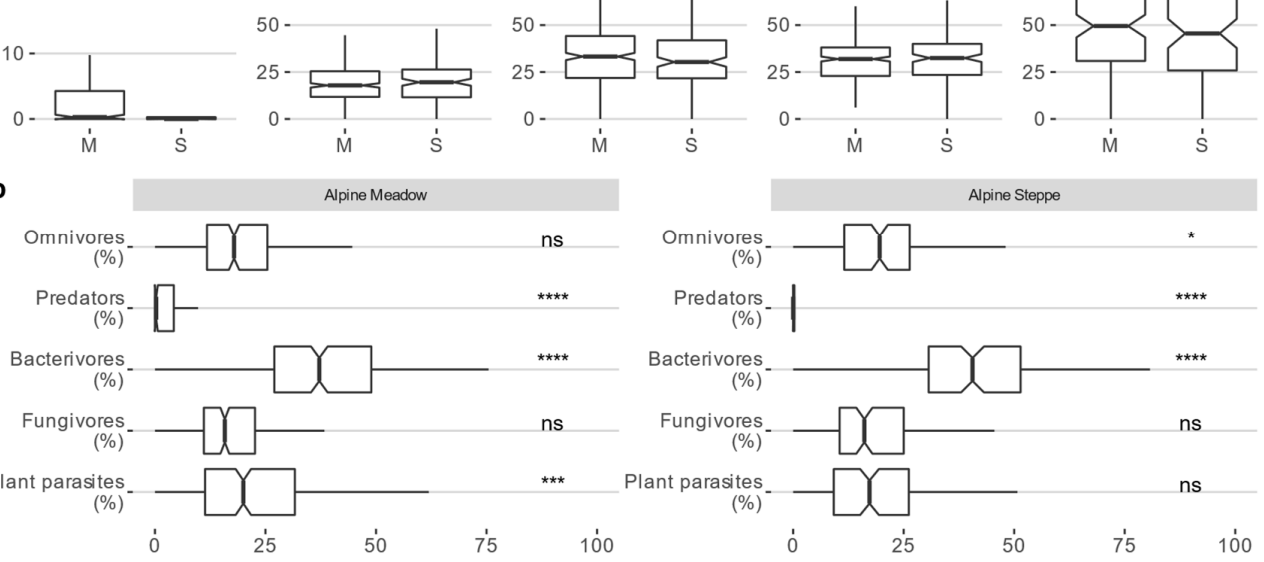

Figure 2. (a) Differences in the taxonomic diversity, trophic groups, and soil food web characteristics of soil nematode communities (median (interquartile range, IQR)) between alpine meadows $(n=360)$ and alpine steppes $(n=160)$. (b) Differences between trophic groups within the ecosystem (Dwass-Steel-Critchlow-Fligner test, $p<0.001$ ). ${ }^{* * * *}: p<0.0001$; $^{* * *}: p<0.001$; $^{* *}: p<0.01$; *: $p<0.05$.

Additionally, Rényi diversities in all the scales in the alpine meadows were higher than those in the alpine steppes (Figure 3). It indicated that soil nematode communities in alpine meadows were regarded as more diverse than those in alpine steppe [53]. 


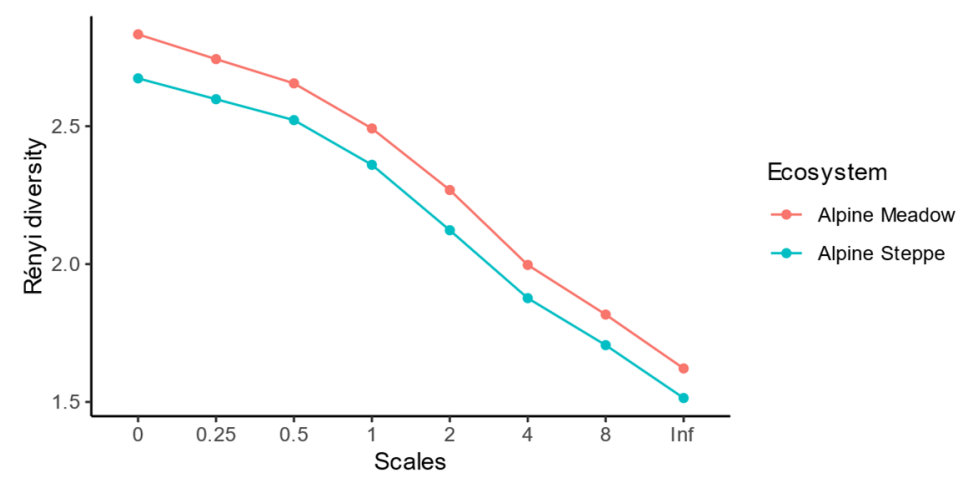

Figure 3. Differences of Rényi diversity of soil nematode communities in multiple scales between alpine meadows and alpine steppes.

\subsection{Effects of Biotic and Abiotic Factors on Nematode Communities}

Plant coverage, biomass, and genus richness were higher in the alpine meadows than in the alpine steppes (Table 1). Such differences were also found for the soil properties, with all the values for the soil properties being higher in the alpine meadows than in the alpine steppes (Table 1), except for soil $\mathrm{pH}$, which showed the opposite pattern (Table 1). This result indicated that the soil was neutral or acidic in the alpine meadows, but alkaline in the alpine steppes. No significant correlation was found between the mean annual temperature/mean annual precipitation and soil moisture in the alpine meadows or alpine steppes (Figure 4).

Table 1. Environmental factors, including the climate, aboveground plants and soil properties (median (interquartile range, IQR)), in alpine meadows $(n=360)$ and alpine steppes $(n=160)$. Bold type indicates significant differences (Wilcoxon rank-sum test). MAT: mean annual temperature $\left({ }^{\circ} \mathrm{C}\right.$ ), MAP: mean annual precipitation (mm), PSR: plant species richness, PBM: plant biomass $\left(\mathrm{g} / \mathrm{m}^{2}\right)$, PCV: plant coverage (\%), pH: soil pH, MOI: soil moisture (\%), TN: total nitrogen (mg/g), TP: total phosphorus (mg/g), AP: available phosphorus (mg/kg), $\mathrm{NH}_{4}$ : ammonium $(\mathrm{mg} / \mathrm{kg}), \mathrm{NO}_{3}$ : nitrate $(\mathrm{mg} / \mathrm{kg})$, SOC: soil organic carbon $(\mathrm{mg} / \mathrm{g})$.

\begin{tabular}{cccc}
\hline & Meadows & Steppes & $p$-Value \\
\hline Climate & & & \\
\hline MAT & $-0.7(3.4)$ & $0.5(4.6)$ & 0.605 \\
MAP & $493.8(226.6)$ & $376.6(227.3)$ & 0.001 \\
\hline Plants & & 0.001 \\
PSR & $16.0(10.0)$ & $10.0(6.0)$ & 0.001 \\
PCV & $85.0(35.0)$ & $30.0(23.0)$ & 0.001 \\
PBM & $357.5(151.7)$ & $46.00(65.6)$ & \\
Soil properties & & & 0.001 \\
pH & $7.2(1.9)$ & $8.2(0.5)$ & 0.001 \\
MOI & $23.9(29.9)$ & $8.0(8.3)$ & 0.001 \\
TN & $3.7(3.4)$ & $1.0(1.2)$ & 0.001 \\
TP & $0.7(0.4)$ & $0.4(0.2)$ & 0.001 \\
AP & $1.3(1.3)$ & $0.4(0.4)$ & 0.001 \\
NH $_{4}$ & $19.3(11.2)$ & $10.0(2.9)$ & 0.001 \\
NO & $6.6(9.2)$ & $3.8(2.9)$ & \\
SOC & $51.7(42.3)$ & $9.7(7.8)$ & \\
\hline
\end{tabular}




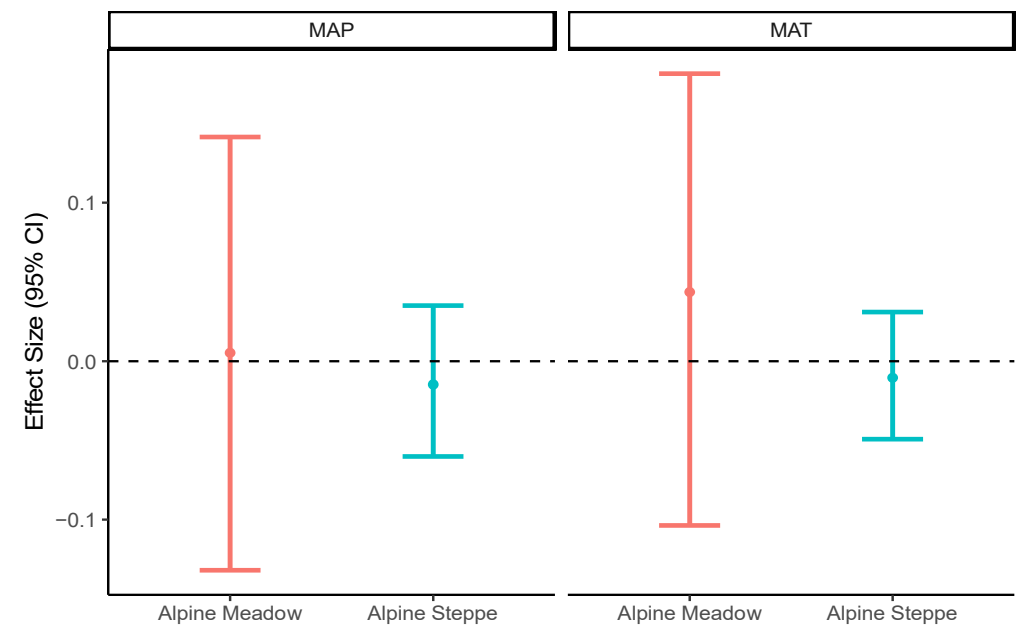

Figure 4. Linear mixed model to evaluate the effect size of climatic factors on soil moisture in alpine meadow and alpine steppe. MAP: mean annual precipitation (mm), MAT: mean annual temperature $\left({ }^{\circ} \mathrm{C}\right)$, MOI: soil moisture $(\%)$.

Overall, the constrained variables in pRDA contributed $2.77-4.54 \%$ to the variance in soil nematode genus composition and trophic composition between ecosystems. According to Figure $5 \mathrm{a}$, the total nitrogen, soil moisture, and ammonium showed significant correlations with the nematode genus composition in the alpine meadow. Total phosphorus, ammonium, and plant species richness significantly correlated with the trophic composition of the soil nematode in both the alpine meadow and alpine steppe (Figure 5b). By the pRDA within each ecosystem, for the nematode genus composition, soil moisture, total nitrogen, and ammonium in alpine meadow, were significantly correlated with either of the first two ordination axes (Figure S1a, Table S4); only nitrate did in the alpine steppe (Figure S1b, Table S4). For the nematode trophic composition, only soil moisture was significantly correlated with either of the first two ordination axes in the alpine meadows (Figure S1c, Table S5); ammonium, plant coverage, and plant biomass significantly did in alpine steppe (Figure S1d, Table S5). Both Figures 5 and S1 showed more data dispersion in the alpine meadows, which indicated to compare to the alpine steppe data, and there was more heterogeneity in the community structure of alpine meadows $[79,80]$. Variation partitioning analysis revealed that the soil properties had the highest contributions to the variations in the nematode genus and trophic composition, not only among all ecosystems, but also within each ecosystem (Figure 6, Figure S2).
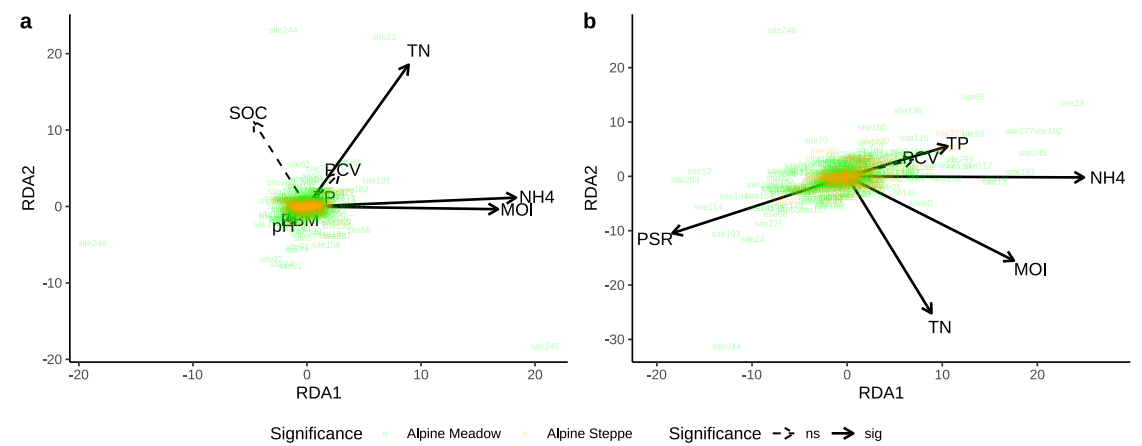

Figure 5. Biplots of partial redundancy analysis of the relationships between the genus composition (a) and trophic composition (b) of nematode community and environmental variables among the alpine meadows and alpine steppes. 

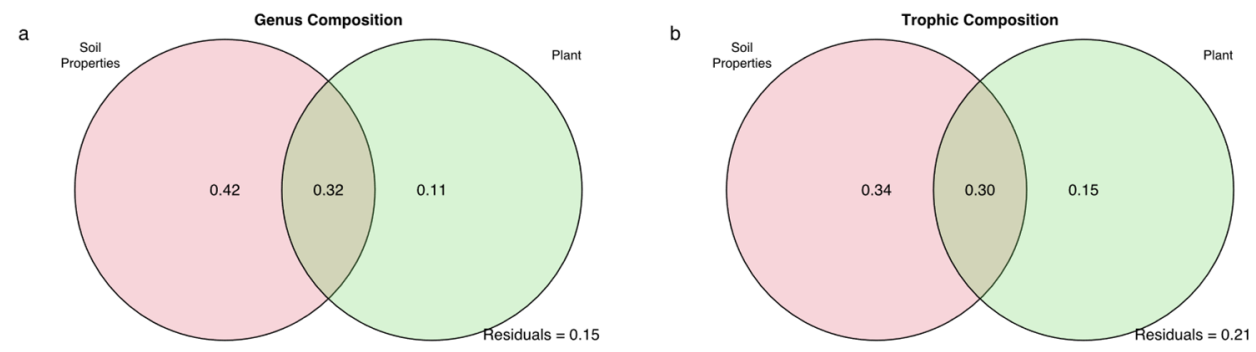

Figure 6. Variation partitioning analyses explained by variable sets of soil properties, aboveground plants and climate for nematode genus (a) and trophic compositions (b) among alpine meadow and alpine steppe. Unique fractions of each explanatory set were evaluated by 9999 permutations.

According to the multiple linear regression, soil moisture was the most frequently selected variable that determined the nematode multiple characteristics in both the ecosystems (Tables S6 and S7). Soil moisture was significantly positively correlated with nematode abundance, genus richness, relative abundance of omnivores, and SI, but negatively correlated with CI (Tables S6 and S7). Furthermore, soil $\mathrm{pH}$ positively related with genus richness in the alpine meadows (Table S6), but negatively did with that in the alpine steppes (Table S7). In the alpine meadows, the total nitrogen and ammonium negatively correlated with nematode abundance, genus richness, relative abundance of omnivores/predators, and SI, simultaneously (Table S6). In contrast, ammonium positively correlated with nematode abundance in the alpine steppe. Together, the soil properties contributed the largest explanation, from 48.36 to $100 \%$, in accounting for the variance in the nematode community characteristics in the alpine meadows. Besides, the soil properties were also essential contributors in accounting for those in the alpine steppes (Table 2).

Table 2. Multiple regression of the effects of environmental variables on soil nematodes. Nematode abundance is calculated as individuals $/ 100 \mathrm{~g}$ of dried soil. Trophic groups, including plant parasites, fungivores, bacterivores, predators, and omnivores, were represented as relative abundances (\%). Soil includes soil property variables that were selected by backward elimination; plant includes all aboveground plant variables that were selected by backward elimination. Detailed contained variables in each variable set are listed in Tables S4 and S5.

\begin{tabular}{ccccc}
\hline & \multicolumn{2}{c}{ Alpine Meadow } & \multicolumn{2}{c}{ Alpine Steppe } \\
\hline & $\begin{array}{c}\text { Soil } \\
\mathbf{( \% )}\end{array}$ & $\begin{array}{c}\text { Plant } \\
\mathbf{( \% )}\end{array}$ & $\begin{array}{c}\text { Soil } \\
\mathbf{( \% )}\end{array}$ & $\begin{array}{c}\text { Plant } \\
\mathbf{( \% )}\end{array}$ \\
\hline $\begin{array}{c}\text { Abundance } \\
\text { (individuals/100 g of dried soil) }\end{array}$ & 100.00 & 0 & 92.19 & 7.81 \\
Genus richness (genus) & 100.00 & 0 & 43.99 & 56.01 \\
Plant parasites (\%) & 100.00 & 0 & & 100.00 \\
Fungivores (\%) & & & 43.77 & 56.23 \\
Bacterivores (\%) & 48.36 & 51.64 & 33.07 & 66.93 \\
Predators (\%) & 95.73 & 4.27 & & \\
Omnivores (\%) & 73.24 & 26.76 & 59.41 & 40.59 \\
EI & 92.97 & 7.03 & 100.00 & 0 \\
SI & 78.70 & 12.30 & 47.84 & 52.16 \\
CI & 100.00 & 0 & 68.37 & 31.63 \\
\hline
\end{tabular}

Plant coverage had similar driving patterns in both the ecosystems, negative correlations with higher trophic level nematodes and SI (Tables S6 and S7). Besides, nematode was associated with more plant characteristics in the alpine steppes, and the variation in soil nematode, explained by plants, was also higher in this ecosystem (Table 2). In the alpine steppes, plant biomass negatively correlated with nematode abundance significantly, genus richness and relative abundance of bacterivores, and positively correlated with fungivores, omnivores, and SI (Table S7). Plant species richness was positively related with 
genus richness and the relative abundance of plant parasites/fungivores, and negatively correlated with bacterivores and SI (Table S7).

\section{Discussion}

\subsection{Difference in Nematode Diversity and Characteristics between Alpine Meadow and} Steppe Ecosystems

We found that alpine meadows had a higher soil nematode abundance and genus richness, and supported more predators than the alpine steppes. The trend of biodiversity between the ecosystems was consistent with this. The differences between the alpine meadow and steppe ecosystems in our study should be determined by the higher resource availability in the soil of the alpine meadows. As unveiled by previous studies, soil nematode diversity was associated with the availability, quantity, and quality of the nutrients in the soil, by a bottom-up pattern [16,81,82]. Ingham et al. [83] suggested that increases in the abundance of predators were induced by increases in the number of soil nematodes on lower trophic levels in the alpine meadows, which was consistent with the finding from the current study. The higher relative abundance of plant parasites in alpine meadows was likely because they were strongly associated with plant status and phenology [84]. The plant litter returned to the soil, the rate of root turnover, and the availability of carbon exuded from the plant into the soil, promote the development of plant parasites [81]. Additionally, high spatial and environmental heterogeneity generally support higher betadiversity $[27,80,85-87]$, and homogeneous landscapes have been shown to support lower diverse communities [88]. Thus, the variety of heterogeneity in turn influences the overall differences in genus richness and abundance between the alpine meadow and steppe.

In contrast to our hypothesis, no differences in the decomposition channel characteristic of soil nematodes were observed between the alpine meadow and steppe. Instead, the bacterial decomposition channel dominated over the fungal decomposition channel in both the systems. This was consistent with the result of a previous study on the soil microbial community in terrestrial ecosystems on the Tibetan Plateau, showing that soil bacteria were dominant compared with fungi [89]. This evidence illustrated that on the Tibetan Plateau, organic matter that was easily decomposed was enriched in soil. Furthermore, the availability of resources in the soil, nutritional conditions, and aboveground plant conditions, improved from the alpine steppe to the alpine meadow, and all the factors detailed above enhanced the survival and diversity of the soil nematodes.

To compare our results with previous studies, we found that the abundance and genus richness of soil nematodes in both the alpine meadows and steppes on the Tibetan Plateau were lower than those reported in other temperate regions of 2318 individuals $/ 100 \mathrm{~g}$ of dried soil and 93.9 species per sample [12,90]. In particular, van den Hoogen et al. [22] revealed relatively high nematode abundance on the Tibetan Plateau, which was quite different from our results. We thought the following two reasons caused this difference: First, with under-sampling being a challenge to an ecology study [91], several studies found that sampling size significantly determined the observations of microbial distribution patterns [92,93], and such a finding could also be generalized to soil nematodes. Compared to other large-scale soil nematode research $[12,16,23,82,94,95]$, our study sampled relatively adequate soil nematode samples (520 soil samples) on the Tibetan Plateau. By comparison, van den Hoogen et al. [22] collected 11 samples at the geographic extent of our case, and under-sampling might lead to weak and biased predictions [91,93]. Second, from the data descriptions of van den Hoogen et al. [22], there were two methods of different nematode extraction efficiencies $[96,97]$, Baermann funnel and Oostenbrink elutriation, which were used in different data sources within the geographical extent of our study. Besides, the ecosystems that were contained in van den Hoogen et al. [22] on the Tibetan Plateau, were constituted by the alpine forest, glacier forefield, alpine meadow, and other undescribed types. In summary, the differences in the methods and sampled ecosystems most likely explained the differences in the results between van den Hoogen et al. [22] and our research. 


\subsection{Roles of Biotic and Abiotic Factors in Relation to the Nematode Community}

Some drivers of soil nematode community composition and characteristics were found in both the ecosystems. For example, the variation in soil nematodes in each ecosystem was largely explained by soil properties. More specifically, soil moisture enhanced the abundance and genus richness of nematodes in both the ecosystems, and promoted an increase in the relative abundance of nematodes at higher trophic levels, which is consistent with previous studies $[4,16,98]$, indicating that soil moisture enhanced nematode resistance and subsequently increased the soil food web complexity [99]. Besides, plant coverage restrained the relative abundance of omnivores and predators in both the ecosystems. This might be explained by the fact that the promotion effect of plant on soil nematodes decreased with the increasing trophic level and omnivory degree of the soil nematode, and eventually suppressed omnivores and predators [100].

However, certain soil properties were only considered as important drivers of soil nematodes diversity in a specific ecosystem. For instance, soil $\mathrm{pH}$ was negatively correlated with soil nematode genus richness in the alpine steppes, where the soil was alkaline, as soil nematodes preferred neutral or acidic soil [101,102]. In the alpine meadows, where the concentration of the nitrogen was four times higher than that in the alpine steppes, the increase in ammonium, mediated by total nitrogen, might have been toxic for the soil nematodes [103], especially for high-trophic-level nematodes [104-106]. Plant factors explained more variations in soil nematode communities in the alpine steppes than in the alpine meadows. We believed that in the alpine steppes, where the soil surface was less covered by plants, the number of microhabitat patches would be significantly regulated by the changes in the plant community composition and biomass $[107,108]$. This process effected the niche of the soil organisms, and further changed their diversity [109,110]. Interestingly, plant variables exhibited different, or even opposite, relationships to the characteristics of the nematode community. For example, both plant species richness and plant biomass showed positive correlations with fungivores and negative correlations with bacterivores, but the relationships of plant species richness and plant biomass with nematode abundance were the opposite. This might be due to different key environmental factors driving the species and functional diversity of nematode communities $[27,111]$, and species and functional diversity responded to environmental changes asynchronously $[9,112-114]$. In summary, at the large scale on the Tibetan Plateau, the effects of soil properties or aboveground plants on the soil nematode community depended on functional type, and these effects could follow distinct patterns under certain environmental conditions as well as resource availability.

Surprisingly, climate factors contributed little to the variations in the nematode communities in both the ecosystems on the Tibetan Plateau. Although climate factors are considered the most essential factors in structuring underground organismal communities $[12,16,21]$, plenty of studies have revealed that soil nematodes are not always sensitive to changes in the mean annual precipitation, as well as the mean annual temperature [37,115-118]. Soil moisture was often considered to be an indicator of precipitation and temperature $[119,120]$; however, no relationship of them was found in our study. Yet, it might be exactly why climate factors did not contribute as strongly to the variation in the soil nematode community as we expected. First, previous studies found snow accumulation and permafrost were crucial factors in determining soil moisture on the Tibetan Plateau; soil organisms were generally well adapted to water shortages and freezing [121,122]. The response of soil organisms to short-term favorable conditions, following thawing and snowmelt, was immediate and short-lived [109], and the annual mean values of precipitation and temperature were not as representative as we expected. Second, Zhou et al. [123] found that the variation in soil moisture on the Tibetan Plateau was non-uniform, and that geographic position and the summer monsoon, together, affected the relationship between precipitation and soil moisture. The heterogeneity of this relationship made the correlation between soil nematodes and climatic factors no longer general at the large scale. Overall, these distinct findings indicated that the variation in soil nematode community composition is highly scale-dependent. 
In this study, a lot of the variation in soil nematode community composition remained unexplained, and it was likely that some important drivers of nematode community composition were not measured. In a meta-analysis on a broad range of terrestrial, marine, and freshwater taxa, Cottenie [124] found an average of approximately $50 \%$ unexplained variation. In cultivated olive trees in Southern Spain, more than two-thirds of the variation remained unexplained by the soil and agricultural management [125]. While, it has been documented that the factors that we measured in this study, including soil moisture, $\mathrm{pH}$, mean annual precipitation, temperature, and plant biomass, were the factors that were most closely related to the soil nematode community [12,25,126,127]. Viketoft [26] also suggested that measuring more microbes could reduce the unexplained variation in nematode community composition. Other studies found soil bulk density [12,81] and soil texture $[128,129]$ to be determinants of the soil nematode community composition. In summary, many challenges still exist in understanding the relationship between environmental factors and soil nematode community composition.

\section{Conclusions}

In this study, we determined the large-scale patterns of soil nematode communities and soil food web characteristics in different alpine ecosystems on the Tibetan Plateau, and explored the factors driving these patterns, by examining biotic and abiotic factors simultaneously. We found that the abundance and genus richness of soil nematodes were limited by harsh conditions. The alpine meadows supported a larger number of individuals and higher diversity of soil nematodes than the alpine steppes, while the energy channels were bacterial-based in both types of ecosystems. The community composition, diversity, and soil food web characteristics of soil nematodes were related to edaphic and plant variables, but not to climate variables (i.e., mean annual precipitation and mean annual temperature). Soil moisture contributed greatly to the diversity of soil nematode communities. In addition, aboveground plants exhibited contributions to the soil nematode community between the ecosystems in our study, which suggested that aboveground plant cover also regulated the soil organismal community from top to bottom, by changing microhabitat patches and increasing nematode habitat availability.

Supplementary Materials: The following are available online at https:/ / www.mdpi.com/article/10 .3390/d13080369/s1, Table S1: description of 104 sites where soil nematode samples were obtained; Table S2: soil nematode genera identified in the grassland on the Tibetan Plateau; Table S3: differences in the taxonomic diversity, trophic groups, and soil food web characteristics of soil nematode communities (median (interquartile range, IQR)) between alpine meadows $(n=360)$ and alpine steppes $(n=160)$. Bold type indicates significant differences (Wilcoxon rank-sum test). Different letters in each column of trophic groups indicate significant differences between trophic groups within the ecosystem (Dwass-Steel-Critchlow-Fligner test, $p<0.001$ ); Table S4: partial redundancy analysis of the relationships between the genus composition of nematode community and environmental variables in the alpine meadows and alpine steppes. $\mathrm{pH}$ : soil $\mathrm{pH}, \mathrm{MOI}$ : soil moisture (\%), TN: total nitrogen $(\mathrm{mg} / \mathrm{g}), \mathrm{NH}_{4}$ : ammonium $(\mathrm{mg} / \mathrm{kg}), \mathrm{NO}_{3}$ : nitrate $(\mathrm{mg} / \mathrm{kg})$, PSR: plant species richness, PBM: plant biomass $\left(\mathrm{g} / \mathrm{m}^{2}\right)$, PCV: plant coverage (\%); Table S5: partial redundancy analysis of the relationships between the trophic composition of nematode community and environmental variables in the alpine meadows and alpine steppes. $\mathrm{pH}$ : soil $\mathrm{pH}, \mathrm{MOI}$ : soil moisture (\%), TN: total nitrogen (mg/g), TP: total phosphorus (mg/g), $\mathrm{NH}_{4}$ : ammonium (mg/kg), PBM: plant biomass $\left(\mathrm{g} / \mathrm{m}^{2}\right), \mathrm{PCV}$ : plant coverage (\%); Table S6: multiple regression of the effects of environmental variables on soil nematodes in the alpine meadows. Nematode's abundance is calculated as individuals $/ 100 \mathrm{~g}$ of dried soil. Richness is the genus richness of nematodes. Trophic groups, such as plant parasites, fungivores, bacterivores, predators and omnivores, are represented as relative abundances (\%). Each individual predictor's contribution was calculated by $l m g$ in the relaimpo package in $R$, which is the $\mathrm{r}^{\wedge} 2$ contribution averaged over orderings among regressors. The $+/-$ symbols indicate positive/negative correlations. $\mathrm{pH}$ : soil $\mathrm{pH}$, MOI: soil moisture (\%), TN: total nitrogen (mg/g), TP: total phosphorus $(\mathrm{mg} / \mathrm{g}), \mathrm{NH}_{4}$ : ammonium $(\mathrm{mg} / \mathrm{kg}), \mathrm{PCV}$ : plant coverage (\%); Table S7: multiple regression of the effects of environmental variables on soil nematodes in the alpine steppes. Nematode's abundance is calculated as individuals/100 $\mathrm{g}$ of dried soil. Richness is the genus richness of nematodes. Trophic 
groups, such as plant parasites, fungivores, bacterivores, predators and omnivores, are represented as relative abundances (\%). The individual predictor's contribution was calculated by lmg in the relaimpo package in $\mathrm{R}$, which is the $\mathrm{r}^{\wedge} 2$ contribution averaged over orderings among regressors. The +/ - symbols indicate positive/negative correlations. $\mathrm{pH}$ : soil $\mathrm{pH}, \mathrm{MOI}$ : soil moisture $(\%), \mathrm{NH}_{4}$ : ammonium $(\mathrm{mg} / \mathrm{kg}), \mathrm{NO}_{3}$ : nitrate $(\mathrm{mg} / \mathrm{kg})$, PBM: plant biomass $\left(\mathrm{g} / \mathrm{m}^{2}\right), \mathrm{PCV}$ : plant coverage $(\%)$, PSR: plant species richness. Figure S1: biplots of partial redundancy analysis of the relationships between the genus composition of nematode community and environmental variables in the alpine meadows (a) and alpine steppes (b), and the relationships between the trophic composition of nematode community and environmental variables in the alpine meadows (c) and alpine steppes (d). pH: soil $\mathrm{pH}, \mathrm{MOI}$ : soil moisture (\%), $\mathrm{TN}$ : total nitrogen $(\mathrm{mg} / \mathrm{g}), \mathrm{NH}_{4}$ : ammonium $(\mathrm{mg} / \mathrm{kg}), \mathrm{NO}_{3}$ : nitrate $(\mathrm{mg} / \mathrm{kg})$, PSR: plant species richness, PBM: plant biomass $\left(\mathrm{g} / \mathrm{m}^{2}\right)$, PCV: plant coverage $(\%)$; Figure S2: variation partitioning analyses explained by variable sets of soil properties, aboveground plants and climate for nematode genus and trophic compositions between alpine meadow and alpine steppe. Unique fractions of each explanatory set were evaluated by 9999 permutations.

Author Contributions: Conceptualization, G.D.; Data curation, H.C.; Funding acquisition, G.D.; Investigation, H.C., S.L., G.L., W.Q., J.H., and G.D.; Methodology, H.C., S.L., G.L., W.Q. and J.H.; Project administration, G.D.; Resources, S.L. and G.L.; Software, H.C. and W.J.; Supervision, G.D.; Validation, M.M. and G.D.; Visualization, H.C. and W.J.; Writing-original draft, H.C., S.L., G.L. and W.J.; Writing-review \& editing, W.Q., M.M. and G.D. All authors have read and agreed to the published version of the manuscript.

Funding: This research was funded by the National Natural Science Foundation of China, grant number 41430749 .

Institutional Review Board Statement: Not applicable.

Data Availability Statement: The data that support the findings of this study are available from the corresponding author upon reasonable request.

Acknowledgments: We thank all members of the State Key Laboratory of Grassland and Agroecosystems, School of Life Sciences, Lanzhou University, for their assistance in the field investigation. We also thank to NOAA/OAR/ESRL PSD, Boulder, Colorado, USA, for providing the UDel_AirT_Precip data used in this study (available on their web site at https:/ / www.esrl.noaa.gov / psd/, accessed on 15 June 2021).

Conflicts of Interest: The authors declare no conflict of interest.

\section{References}

1. Lambshead, P.J.D. Recent Developments in Marine Benthic Biodiversity Reserch. Oceanis 1993, 19, 5-24.

2. Yeates, G.W.; Bongers, T.; De Goede, R.G.M.; Freckman, D.W.; Georgieva, S.S. Feeding Habits in Soil Nematode Families and Genera-an Outline for Soil Ecologists. J. Nematol. 1993, 25, 315-331.

3. Bongers, T.; Bongers, M. Functional Diversity of Nematodes. Appl. Soil Ecol. 1998, 10, 239-251. [CrossRef]

4. Laakso, J.; Setälä, H. Population- and Ecosystem-Level Effects of Predation on Microbial-Feeding Nematodes. Oecologia 1999, 120, 279-286. [CrossRef]

5. Scheu, S. The Soil Food Web: Structure and Perspectives. Eur. J. Soil Biol. 2002, 38, 11-20. [CrossRef]

6. Zhao, J.; Neher, D.A. Soil Energy Pathways of Different Ecosystems Using Nematode Trophic Group Analysis: A Meta Analysis. Nematology 2014, 16, 379-385. [CrossRef]

7. Ferris, H.; Bongers, T.; de Goede, R.G.M. A Framework for Soil Food Web Diagnostics: Extension of the Nematode Faunal Analysis Concept. Appl. Soil Ecol. 2001, 18, 13-29. [CrossRef]

8. Freckman, D.W.; Ettema, C.H. Assessing Nematode Communities in Agroecosystems of Varying Human Intervention. Agric. Ecosyst. Environ. 1993, 45, 239-261. [CrossRef]

9. Yeates, G.W. Nematodes as Soil Indicators: Functional and Biodiversity Aspects. Biol. Fertil. Soils 2003, 37, 199-210. [CrossRef]

10. Ritz, K.; Trudgill, D.L. Utility of Nematode Community Analysis as an Integrated Measure of the Functional State of Soils: Perspectives and Challenges. Plant Soil 1999, 212, 1-11. [CrossRef]

11. Yeates, G.; Boag, B. Background for nematode ecology in the 21st century. In Nematology: Advances and Perspectives; CABI Publishing: Wallingford, UK, 2004; Volume 1, pp. 406-437.

12. Nielsen, U.N.; Ayres, E.; Wall, D.H.; Li, G.; Bardgett, R.D.; Wu, T.; Garey, J.R. Global-scale Patterns of Assemblage Structure of Soil Nematodes in Relation to Climate and Ecosystem Properties. Glob. Ecol. Biogeogr. 2014, 23, 968-978. [CrossRef] 
13. Pey, B.; Nahmani, J.; Auclerc, A.; Capowiez, Y.; Cluzeau, D.; Cortet, J.; Decaëns, T.; Deharveng, L.; Dubs, F.; Joimel, S.; et al. Current Use of and Future Needs for Soil Invertebrate Functional Traits in Community Ecology. Basic Appl. Ecol. 2014, 15, 194-206. [CrossRef]

14. Geisen, S.; Briones, M.J.I.; Gan, H.; Behan-Pelletier, V.M.; Friman, V.-P.; de Groot, G.A.; Hannula, S.E.; Lindo, Z.; Philippot, L.; Tiunov, A.V.; et al. A Methodological Framework to Embrace Soil Biodiversity. Soil Biol. Biochem. 2019, 136, 107536. [CrossRef]

15. Fierer, N.; Strickland, M.S.; Liptzin, D.; Bradford, M.A.; Cleveland, C.C. Global Patterns in Belowground Communities. Ecol. Lett. 2009, 12, 1238-1249. [CrossRef]

16. Chen, D.; Cheng, J.; Chu, P.; Hu, S.; Xie, Y.; Tuvshintogtokh, I.; Bai, Y. Regional-scale Patterns of Soil Microbes and Nematodes across Grasslands on the Mongolian Plateau: Relationships with Climate, Soil, and Plants. Ecography 2015, 38, 622-631. [CrossRef]

17. Zhao, J.; Xun, R.; He, X.; Zhang, W.; Fu, W.; Wang, K. Size Spectra of Soil Nematode Assemblages under Different Land Use Types. Soil Biol. Biochem. 2015, 85, 130-136. [CrossRef]

18. Jing, X.; Sanders, N.J.; Shi, Y.; Chu, H.; Classen, A.T.; Zhao, K.; Chen, L.; Shi, Y.; Jiang, Y.; He, J.-S. The Links between Ecosystem Multifunctionality and Above- and Belowground Biodiversity Are Mediated by Climate. Nat. Commun. 2015, 6, 8159. [CrossRef] [PubMed]

19. Neher, D.A. Nematode Communities in Organically and Conventionally Managed Agricultural Soils. J. Nematol. 1999, 31, 142-154.

20. Ruan, W.; Sang, Y.; Chen, Q.; Zhu, X.; Lin, S.; Gao, Y. The Response of Soil Nematode Community to Nitrogen, Water, and Grazing History in the Inner Mongolian Steppe, China. Ecosystems 2012, 15, 1121-1133. [CrossRef]

21. Ruess, L.; Michelsen, A.; Schmidt, I.K.; Jonasson, S. Simulated Climate Change Affecting Microorganisms, Nematode Density and Biodiversity in Subarctic Soils. Plant Soil 1999, 212, 63-73. [CrossRef]

22. Van den Hoogen, J.; Geisen, S.; Routh, D.; Ferris, H.; Traunspurger, W.; Wardle, D.A.; de Goede, R.G.M.; Adams, B.J.; Ahmad, W.; Andriuzzi, W.S.; et al. Soil Nematode Abundance and Functional Group Composition at a Global Scale. Nature 2019, 572, 194-198. [CrossRef]

23. Wu, J.; Chen, H.; Zhang, Y. Latitudinal Variation in Nematode Diversity and Ecological Roles along the Chinese Coast. Ecol. Evol. 2016, 6, 8018-8027. [CrossRef]

24. Traunspurger, W.; Reiff, N.; Krashevska, V.; Majdi, N.; Scheu, S. Diversity and Distribution of Soil Micro-Invertebrates across an Altitudinal Gradient in a Tropical Montane Rainforest of Ecuador, with Focus on Free-Living Nematodes. Pedobiologia 2017, 62, 28-35. [CrossRef]

25. Liu, T.; Hu, F.; Li, H. Spatial Ecology of Soil Nematodes: Perspectives from Global to Micro Scales. Soil Biol. Biochem. 2019, 137, 107565. [CrossRef]

26. Viketoft, M. Determinants of Small-Scale Spatial Patterns: Importance of Space, Plants and Abiotics for Soil Nematodes. Soil Biol. Biochem. 2013, 62, 92-98. [CrossRef]

27. Li, X.; Zhu, H.; Geisen, S.; Bellard, C.; Hu, F.; Li, H.; Chen, X.; Liu, M. Agriculture Erases Climate Constraints on Soil Nematode Communities across Large Spatial Scales. Glob. Chang. Biol. 2020, 26, 919-930. [CrossRef]

28. Zhou, Z.; Wang, C.; Luo, Y. Meta-Analysis of the Impacts of Global Change Factors on Soil Microbial Diversity and Functionality. Nat. Commun. 2020, 11, 1-10. [CrossRef]

29. Li, W.; Zhou, X. Ecosystems of Qinghai-Xizang (Tibetan) Plateau and Approach for Their Sustainable Manag; The series of studies on Qinghai-Xizang (Tibetan) Plateau; Guang-dong Science \& Technology Press: Guangzhou, China, 1998; ISBN 978-7-5359-1945-8.

30. Li, X.-L.; Gao, J.; Brierley, G.; Qiao, Y.-M.; Zhang, J.; Yang, Y.-W. Rangeland degradation on the oinghai-tibet plateau: Implications for rehabilitation. Land Degrad. Develop. 2013, 24, 72-80. [CrossRef]

31. Qi, W.; Zhou, X.; Ma, M.; Knops, J.M.H.; Li, W.; Du, G. Elevation, Moisture and Shade Drive the Functional and Phylogenetic Meadow Communities' Assembly in the Northeastern Tibetan Plateau. Community Ecol. 2015, 16, 66-75. [CrossRef]

32. Ma, M.; Dalling, J.W.; Ma, Z.; Zhou, X. Soil Environmental Factors Drive Seed Density across Vegetation Types on the Tibetan Plateau. Plant. Soil 2017, 374, 1-13. [CrossRef]

33. Wu, H.; Guo, Z.; Peng, C. Distribution and Storage of Soil Organic Carbon in China: Soil organic carbon in China. Glob. Biogeochem. Cycles. 2003, 17, 1043. [CrossRef]

34. Han, L. Viewing the Sustainable Development of the Qinghai-Tibet Plateau from Water Resources System. IOP Conf. Ser. Earth Environ. Sci. 2018, 170, 032083. [CrossRef]

35. Mu, C.; Abbott, B.W.; Norris, A.J.; Mu, M.; Fan, C.; Chen, X.; Jia, L.; Yang, R.; Zhang, T.; Wang, K.; et al. The Status and Stability of Permafrost Carbon on the Tibetan Plateau. Earth-Sci. Rev. 2020, 211, 103433. [CrossRef]

36. Bardgett, R.D.; Wardle, D.A. Oxford Series in Ecology and Evolution. In Aboveground-Belowground Linkages; Oxford University Press: Oxford, UK, 2010; ISBN 978-0-19-954688-6.

37. De Vries, F.T.; Manning, P.; Tallowin, J.R.B.; Mortimer, S.R.; Pilgrim, E.S.; Harrison, K.A.; Hobbs, P.J.; Quirk, H.; Shipley, B.; Cornelissen, J.H.C.; et al. Abiotic Drivers and Plant Traits Explain Landscape-Scale Patterns in Soil Microbial Communities. Ecol. Lett. 2012, 15, 1230-1239. [CrossRef] [PubMed]

38. Wang, C.-P.; Huang, M.-T.; Zhai, P.-M. Change in Drought Conditions and Its Impacts on Vegetation Growth over the Tibetan Plateau. Adv. Clim. Chang. Res. 2021, 12, 333-341. [CrossRef]

39. Piao, S.; Zhang, X.; Wang, T.; Liang, E.; Wang, S.; Zhu, J.; Niu, B. Responses and Feedback of the Tibetan Plateau's Alpine Ecosystem to Climate Change. Chin. Sci. Bull. 2019, 64, 2842-2855. [CrossRef] 
40. Zhu, Z.; Piao, S.; Myneni, R.B.; Huang, M.; Zeng, Z.; Canadell, J.G.; Ciais, P.; Sitch, S.; Friedlingstein, P.; Arneth, A.; et al. Greening of the Earth and Its Drivers. Nat. Clim. Chang. 2016, 6, 791-795. [CrossRef]

41. Hu, Y.; Wang, S.; Niu, B.; Chen, Q.; Wang, J.; Zhao, J.; Luo, T.; Zhang, G. Effect of Increasing Precipitation and Warming on Microbial Community in Tibetan Alpine Steppe. Environ. Res. 2020, 189, 109917. [CrossRef]

42. Zhao, J.; Luo, T.; Wei, H.; Deng, Z.; Li, X.; Li, R.; Tang, Y. Increased Precipitation Offsets the Negative Effect of Warming on Plant Biomass and Ecosystem Respiration in a Tibetan Alpine Steppe. Agric. For. Meteorol. 2019, 279, 107761. [CrossRef]

43. Zhao, K.; Jing, X.; Sanders, N.J.; Chen, L.; Shi, Y.; Flynn, D.F.B.; Wang, Y.; Chu, H.; Liang, W.; He, J.-S. On the Controls of Abundance for Soil-Dwelling Organisms on the Tibetan Plateau. Ecosphere 2017, 8, e01901. [CrossRef]

44. Bell, C.W.; Acosta-Martinez, V.; McIntyre, N.E.; Cox, S.; Tissue, D.T.; Zak, J.C. Linking Microbial Community Structure and Function to Seasonal Differences in Soil Moisture and Temperature in a Chihuahuan Desert Grassland. Microb Ecol. 2009, 58, 827-842. [CrossRef]

45. Geng, Y.; Wang, Y.; Yang, K.; Wang, S.; Zeng, H.; Baumann, F.; Kuehn, P.; Scholten, T.; He, J.-S. Soil Respiration in Tibetan Alpine Grasslands: Belowground Biomass and Soil Moisture, but Not Soil Temperature, Best Explain the Large-Scale Patterns. PLOS ONE 2012, 7, e34968. [CrossRef] [PubMed]

46. Ma, M.; Collins, S.L.; Du, G. Direct and Indirect Effects of Temperature and Precipitation on Alpine Seed Banks in the Tibetan Plateau. Ecol. Appl. 2020, 30. [CrossRef] [PubMed]

47. Yao, H.; Campbell, C.D.; Chapman, S.J.; Freitag, T.E.; Nicol, G.W.; Singh, B.K. Multi-Factorial Drivers of Ammonia Oxidizer Communities: Evidence from a National Soil Survey: Multi-Factorial Drivers of Ammonia Oxidizer Communities. Environ. Microbiol. 2013, 15, 2545-2556. [CrossRef] [PubMed]

48. Chen, D.; Mi, J.; Chu, P.; Cheng, J.; Zhang, L.; Pan, Q.; Xie, Y.; Bai, Y. Patterns and Drivers of Soil Microbial Communities along a Precipitation Gradient on the Mongolian Plateau. Landsc. Ecol. 2014, 30, 1669-1682. [CrossRef]

49. Southey, J.F. Laboratory Methods for Work with Plant. and Soil Nematodes, 6th ed.; H.M.S.O. Books: London, UK, 1986; ISBN 0-11-242754-5.

50. Goodey, T.; Goodey, J.B. Soil and Freshwater Nematodes, 2nd ed.; Methuen, Wiley: London, UK, 1963; ISBN B0019Y180M.

51. Jairajpuri, M.S.; Ahmad, W. Dorylaimida: Free-Living, Predaceous and Plant.-Parasitic Nematodes; Brill: Leiden, The Netherlands; New York, NY, USA, 1992; ISBN 978-90-04-09229-7.

52. Warwick, R.M.; Platt, H.M.; Somerfield, P.J. Freeliving Marine Nematodes: Part. III. Monhysterida. Synopses of the British Fauna No. 53; Field Studies Council: Shrewsbury, UK, 1998.

53. Tóthmérész, B. Comparison of Different Methods for Diversity Ordering. J. Veg. Sci. 1995, 6, 283-290. [CrossRef]

54. Kindt, R.; Van Damme, P.; Simons, A.J. Tree diversity in western Kenya: Using profiles to characterise richness and evenness. In Forest Diversity and Management; Hawksworth, D.L., Bull, A.T., Eds.; Topics in Biodiversity and Conservation; Springer: Dordrecht, The Netherland, 2006; pp. 193-210. ISBN 978-1-4020-5208-8.

55. Gardner, W.H. Water Content. In Methods of Soil Analysis; Klute, A., Ed.; American Society of Agronomy: Madison, WI, USA, 1965; pp. 82-187. ISBN 978-0-89118-811-7.

56. Allen, W.; Armstrong, B.I. An Examination of the Degtjareff Method for Determining Soil Organic Matter, and a Proposed Modification of the Chromic Acid Titration Method. Soil Sci. 1934, 37, 29-38. [CrossRef]

57. Bray, B.; Kurtz, L.T. Determination of Total, Organic, and Available Forms of Phosphorus in Soils. Soil Sci. 1945, 59, 39-46. [CrossRef]

58. Bao, S. Soil Agro-Chemistrical Analysis (in Chinese), 1st ed.; Textbook Series for 21st Century; Chinese Agricultural Press: Beijing, China, 2000; ISBN 978-7-109-06644-1.

59. Cort J., W.; Kenji, M. University of Delaware Air Temperature \& Precipitation (V5.01). Available online: https: / / www.esrl.noaa gov/psd/data/gridded/data.UDel_AirT_Precip.html (accessed on 10 December 2019).

60. Legates, D.R.; Willmott, C.J. Mean Seasonal and Spatial Variability in Global Surface Air Temperature. Appl. Clim. 1990, 41, 11-21. [CrossRef]

61. Willmott, C.J.; Matsuura, K. Smart Interpolation of Annually Averaged Air Temperature in the United States. J. Appl. Meteor. 1995, 34, 2577-2586. [CrossRef]

62. Willmott, C.J.; Rowe, C.M.; Philpot, W.D. Small-Scale Climate Maps: A Sensitivity Analysis of Some Common Assumptions Associated with Grid-Point Interpolation and Contouring. Am. Cartogr. 1985, 12, 5-16. [CrossRef]

63. Willmott, C.J.; Robeson, S.M. Climatologically aided interpolation (CAI) of terrestrial air temperature. Int. J. Climatol. 1995, 15, 221-229. [CrossRef]

64. Koutsouris, A.J.; Chen, D.; Lyon, S.W. Comparing Global Precipitation Data Sets in Eastern Africa: A Case Study of Kilombero Valley, Tanzania: Comparing Global Precipitation Data Sets in Tanzania, East Africa. Int. J. Climatol. 2016, 36, $2000-2014$. [CrossRef]

65. Hosseini-Moghari, S.-M.; Araghinejad, S.; Ebrahimi, K. Spatio-Temporal Evaluation of Global Gridded Precipitation Datasets across Iran. Hydrol. Sci. J. 2018, 63, 1669-1688. [CrossRef]

66. Kanda, N.; Negi, H.S.; Rishi, M.; Kumar, A. Performance of Various Gridded Temperature and Precipitation Datasets over Northwest Himalayan Region. Environ. Res. Commun. 2020, 2, 085002. [CrossRef]

67. Oksanen, J.; Kindt, R.; Legendre, P.; Hara, B.; Henry, M.; Stevens, H. The Vegan Package. Community Ecol. Package 2007, 10, 719. 
68. Wickham, H.; Chang, W.; Henry, L.; Pedersen, T.L.; Takahashi, K.; Wilke, C.; Woo, K.; Yutani, H.; RStudio. Ggplot2: Create Elegant Data Visualisations Using the Grammar of Graphics. 2019. Available online: https:/ /CRAN.R-project.org/package=ggplot2 (accessed on 15 June 2021).

69. Douglas, C.E.; Michael, F.A. On Distribution-Free Multiple Comparisons in the One-Way Analysis of Variance. Commun. Stat. Theory Methods 1991, 20, 127-139. [CrossRef]

70. Hsu, J. Multiple Comparisons: Theory and Methods, 1st ed.; Chapman and Hall/CRC: London, UK, 1996; ISBN 978-0-412-98281-1.

71. Borcard, D.; Legendre, P.; Drapeau, P. Partialling out the Spatial Component of Ecological Variation. Ecology 1992, 73, 1045-1055. [CrossRef]

72. Legendre, P.; Legendre, L.; Legendre, L.; Legendre, L. Developments in environmental modelling. In Numerical Ecology, 2nd ed.; Elsevier: Amsterdam, The Netherlands, 1998; ISBN 978-0-444-89249-2.

73. Legendre, P.; Oksanen, J.; Braak, C.J.F. ter Testing the Significance of Canonical Axes in Redundancy Analysis. Methods Ecol. Evol. 2011, 2, 269-277. [CrossRef]

74. Peres-Neto, P.R.; Legendre, P.; Dray, S.; Borcard, D. Variation Partitioning of Species Data Matrices: Estimation and Comparison of Fractions. Ecology 2006, 87, 2614-2625. [CrossRef]

75. Lindeman, R.H.; Merenda, P.F.; Gold, R.Z. Introduction to Bivariate and Multivariate Analysis; Scott Foresman: Brook, IL, USA, 1980; ISBN 978-0-673-15099-8.

76. Groemping, U.; Matthias, L. Relaimpo: Relative Importance of Regressors in Linear Models. 2018. Available online: https:/ /CRAN.Rproject.org/package=relaimpo (accessed on 15 June 2021).

77. Harrison, X.A.; Donaldson, L.; Correa-Cano, M.E.; Evans, J.; Fisher, D.N.; Goodwin, C.E.D.; Robinson, B.S.; Hodgson, D.J.; Inger, R. A Brief Introduction to Mixed Effects Modelling and Multi-Model Inference in Ecology. Peer] 2018, 6. [CrossRef]

78. Berkelmans, R.; Ferris, H.; Tenuta, M.; van Bruggen, A.H.C. Effects of Long-Term Crop Management on Nematode Trophic Levels Other than Plant Feeders Disappear after 1 Year of Disruptive Soil Management. Appl. Soil Ecol. 2003, 23, 223-235. [CrossRef]

79. Anderson, M.J.; Willis, T.J. Canonical Analysis of Principal Coordinates: A Useful Method of Constrained Ordination for Ecology. Ecology 2003, 84, 511-525. [CrossRef]

80. Anderson, M.J.; Ellingsen, K.E.; McArdle, B.H. Multivariate Dispersion as a Measure of Beta Diversity. Ecol. Lett. 2006, 9, 683-693. [CrossRef] [PubMed]

81. Sanchez-Moreno, S.; Minoshima, H.; Ferris, H.; Jackson, L.E. Linking Soil Properties and Nematode Community Composition: Effects of Soil Management on Soil Food Webs. Nematology 2006, 8, 703-715. [CrossRef]

82. Nielsen, U.N.; Osler, G.H.R.; Campbell, C.D.; Burslem, D.F.R.P.; van der Wal, R. The Influence of Vegetation Type, Soil Properties and Precipitation on the Composition of Soil Mite and Microbial Communities at the Landscape Scale. J. Biogeogr. 2010, 37, 1317-1328. [CrossRef]

83. Ingham, E.R.; Moldenke, A.R.; Edwards, C.A. Soil Biology Primer; Tugel, A.J., Lewandowski, A.M., Happe-vonArb, D., Eds.; Soil and Water Conservation Society: Ankeny, IA, USA, 2000.

84. Yeates, G.W.; Wardle, D.A.; Watson, R.N. Responses of Soil Nematode Populations, Community Structure, Diversity and Temporal Variability to Agricultural Intensification over a Seven-Year Period. Soil Biol. Biochem. 1999, 31, 1721-1733. [CrossRef]

85. Freestone, A.L.; Inouye, B.D. Dispersal Limitation and Environmental Heterogeneity Shape Scale-Dependent Diversity Patterns in Plant Communities. Ecology 2006, 87, 2425-2432. [CrossRef]

86. Horner-Devine, M.C.; Carney, K.M.; Bohannan, B.J.M. An Ecological Perspective on Bacterial Biodiversity. Proc. R. Soc. London Ser. B Biol. Sci. 2004, 271, 113-122. [CrossRef]

87. Ranjard, L.; Dequiedt, S.; Chemidlin Prévost-Bouré, N.; Thioulouse, J.; Saby, N.P.A.; Lelievre, M.; Maron, P.A.; Morin, F.E.R.; Bispo, A.; Jolivet, C.; et al. Turnover of Soil Bacterial Diversity Driven by Wide-Scale Environmental Heterogeneity. Nat. Commun. 2013, 4, 1434. [CrossRef]

88. Flynn, D.F.B.; Gogol-Prokurat, M.; Nogeire, T.; Molinari, N.; Richers, B.T.; Lin, B.B.; Simpson, N.; Mayfield, M.M.; DeClerck, F. Loss of Functional Diversity under Land Use Intensification across Multiple Taxa. Ecol. Lett. 2009, 12, 22-33. [CrossRef] [PubMed]

89. Chen, Y.; Ding, J.; Peng, Y.; Li, F.; Yang, G.; Liu, L.; Qin, S.-Q.; Fang, K.; Yang, Y.-H. Patterns and Drivers of Soil Microbial Communities in Tibetan Alpine and Global Terrestrial Ecosystems. J. Biogeogr. 2016, 43, 2027-2039. [CrossRef]

90. Boag, B.; Yeates, G.W. Soil Nematode Biodiversity in Terrestrial Ecosystems. Biodivers. Conserv. 1998, 7, 617-630. [CrossRef]

91. Cam, E.; Nichols, J.D.; Hines, J.E.; Sauer, J.R.; Alpizar-Jara, R.; Flather, C.H. Disentangling Sampling and Ecological Explanations Underlying Species-Area Relationships. Ecology 2002, 83, 1118-1130. [CrossRef]

92. Woodcock, S.; Curtis, T.P.; Head, I.M.; Lunn, M.; Sloan, W.T. Taxa-Area Relationships for Microbes: The Unsampled and the Unseen. Ecol. Lett. 2006, 9, 805-812. [CrossRef]

93. Meyer, K.M.; Memiaghe, H.; Korte, L.; Kenfack, D.; Alonso, A.; Bohannan, B.J.M. Why Do Microbes Exhibit Weak Biogeographic Patterns? ISME J. 2018, 12, 1404-1413. [CrossRef]

94. Kerfahi, D.; Tripathi, B.M.; Porazinska, D.L.; Park, J.; Go, R.; Adams, J.M. Do Tropical Rain Forest Soils Have Greater Nematode Diversity than High Arctic Tundra? A Metagenetic Comparison of Malaysia and Svalbard. Glob. Ecol. Biogeogr. 2016, 25, 716-728. [CrossRef]

95. Kergunteuil, A.; Campos-Herrera, R.; Sánchez-Moreno, S.; Vittoz, P.; Rasmann, S. The Abundance, Diversity, and Metabolic Footprint of Soil Nematodes Is Highest in High Elevation Alpine Grasslands. Front. Ecol. Evol. 2016, 4, 84. [CrossRef] 
96. Oostenbrink, M. Estimating nematode populations by some selected methods. In Nematology; University of North Carolina Press: Chapel Hill, NC, USA, 1960; pp. 85-102.

97. Bezooijen, J. van Methods and Techniques for Nematology; Wageningen University: Wageningen, The Netherlands, 2006.

98. Denton, C.S.; Bardgett, R.D.; Cook, R.; Hobbs, P.J. Low Amounts of Root Herbivory Positively Influence the Rhizosphere Microbial Community in a Temperate Grassland Soil. Soil Biol. Biochem. 1998, 31, 155-165. [CrossRef]

99. Sun, F.; Pan, K.; Tariq, A.; Zhang, L.; Sun, X.; Li, Z.; Wang, S.; Xiong, Q.; Song, D.; Olatunji, O.A. The Response of the Soil Microbial Food Web to Extreme Rainfall under Different Plant Systems. Sci. Rep. 2016, 6, 1-12. [CrossRef]

100. Scherber, C.; Eisenhauer, N.; Weisser, W.W.; Schmid, B.; Voigt, W.; Fischer, M.; Schulze, E.-D.; Roscher, C.; Weigelt, A.; Allan, E.; et al. Bottom-up Effects of Plant Diversity on Multitrophic Interactions in a Biodiversity Experiment. Nature 2010, 468, 553-556. [CrossRef]

101. Wang, C.; Bruening, G.; Williamson, V.M. Determination of Preferred PH for Root-Knot Nematode Aggregation Using Pluronic F-127 Gel. J. Chem. Ecol. 2009, 35, 1242-1251. [CrossRef] [PubMed]

102. Matute, M.M. Soil Nematodes of Brassica Rapa: Influence of Temperature and PH. Adv. Nat. Sci. 2013, 6, 20-26. [CrossRef]

103. Wei, C.; Zheng, H.; Li, Q.; Lü, X.; Yu, Q.; Zhang, H.; Chen, Q.; He, N.; Kardol, P.; Liang, W.; et al. Nitrogen Addition Regulates Soil Nematode Community Composition through Ammonium Suppression. PLOS ONE 2012, 7, e43384. [CrossRef]

104. Bongers, T. The Maturity Index: An Ecological Measure of Environmental Disturbance Based on Nematode Species Composition. Oecologia 1990, 83, 14-19. [CrossRef]

105. Bongers, T.; Ferris, H. Nematode Community Structure as a Bioindicator in Environmental Monitoring. Trends Ecol. Evol. 1999, 14, 224-228. [CrossRef]

106. Neher, D.; Weicht, T. Nematode Genera in Forest Soil Respond Differentially to Elevated CO2. J. Nematol. $2013,45,214-222$.

107. Landsman, A.P.; Ladin, Z.S.; Gardner, D.; Bowman, J.L.; Shriver, G.; D’Amico, V.; Delaney, D.A. Local Landscapes and Microhabitat Characteristics Are Important Determinants of Urban-Suburban Forest Bee Communities. Ecosphere 2019, 10, e02908. [CrossRef]

108. Li, Y.-G.; Zhou, X.-B.; Zhang, Y.-M. Moss Patch Size and Microhabitats Influence Stoichiometry of Moss Crusts in a Temperate Desert, Central Asia. Plant. Soil. 2019, 443, 55-72. [CrossRef]

109. Devetter, M.; Háněl, L.; Řeháková, K.; Doležal, J. Diversity and Feeding Strategies of Soil Microfauna along Elevation Gradients in Himalayan Cold Deserts. PLOS ONE 2017, 12, e0187646. [CrossRef]

110. Bach, E.M.; Williams, R.J.; Hargreaves, S.K.; Yang, F.; Hofmockel, K.S. Greatest Soil Microbial Diversity Found in Micro-Habitats. Soil Biol. Biochem. 2018, 118, 217-226. [CrossRef]

111. Wang, Y.; Niu, K. Effect of soil environment on functional diversity of soil nematodes in Tibetan alpine meadows. Biodivers. Sci. 2020, 28, 707-717. [CrossRef]

112. Flynn, D.F.B.; Mirotchnick, N.; Jain, M.; Palmer, M.I.; Naeem, S. Functional and Phylogenetic Diversity as Predictors of Biodiversity-Ecosystem-Function Relationships. Ecology 2011, 92, 1573-1581. [CrossRef]

113. Niu, K.; Choler, P.; de Bello, F.; Mirotchnick, N.; Du, G.; Sun, S. Fertilization Decreases Species Diversity but Increases Functional Diversity: A Three-Year Experiment in a Tibetan Alpine Meadow. Agric. Ecosyst. Environ. 2014, 182, 106-112. [CrossRef]

114. Enquist, B.J.; Norberg, J.; Bonser, S.P.; Violle, C.; Webb, C.T.; Henderson, A.; Sloat, L.L.; Savage, V.M. Chapter Nine-Scaling from Traits to Ecosystems: Developing a General Trait Driver Theory via Integrating Trait-Based and Metabolic Scaling Theories. In Advances in Ecological Research; Pawar, S., Woodward, G., Dell, A.I., Eds.; Trait-Based Ecology-From Structure to Function; Academic Press: Cambridge, MA, USA, 2015; Volume 52, pp. 249-318.

115. Haimi, J.; Laamanen, J.; Penttinen, R.; Räty, M.; Koponen, S.; Kellomäki, S.; Niemelä, P. Impacts of Elevated CO2 and Temperature on the Soil Fauna of Boreal Forests. Appl. Soil Ecol. 2005, 30, 104-112. [CrossRef]

116. Darby, B.J.; Neher, D.A.; Housman, D.C.; Belnap, J. Few Apparent Short-Term Effects of Elevated Soil Temperature and Increased Frequency of Summer Precipitation on the Abundance and Taxonomic Diversity of Desert Soil Micro- and Meso-Fauna. Soil Biol. Biochem. 2011, 43, 1474-1481. [CrossRef]

117. Dequiedt, S.; Saby, N.P.A.; Lelievre, M.; Jolivet, C.; Thioulouse, J.; Toutain, B.; Arrouays, D.; Bispo, A.; Lemanceau, P.; Ranjard, L. Biogeographical Patterns of Soil Molecular Microbial Biomass as Influenced by Soil Characteristics and Management. Glob. Ecol. Biogeogr. 2011, 20, 641-652. [CrossRef]

118. Eisenhauer, N.; Cesarz, S.; Koller, R.; Worm, K.; Reich, P.B. Global Change Belowground: Impacts of Elevated CO2, Nitrogen, and Summer Drought on Soil Food Webs and Biodiversity. Glob. Chang. Biol. 2011, 18, 435-447. [CrossRef]

119. Jones, A.R.; Brunsell, N.A. A Scaling Analysis of Soil Moisture-Precipitation Interactions in a Regional Climate Model. Theor. Appl. Climatol. 2009, 98, 221-235. [CrossRef]

120. Duerinck, H.M.; van der Ent, R.J.; van de Giesen, N.C.; Schoups, G.; Babovic, V.; Yeh, P.J.F. Observed Soil Moisture-Precipitation Feedback in Illinois: A Systematic Analysis over Different Scales. J. Hydrometeorol. 2016, 17, 1645-1660. [CrossRef]

121. Wang, G.; Li, Y.; Wu, Q.; Wang, Y. Impacts of Permafrost Changes on Alpine Ecosystem in Qinghai-Tibet Plateau. Sci. China Ser. D 2006, 49, 1156-1169. [CrossRef]

122. Yang, K.; Wu, H.; Qin, J.; Lin, C.; Tang, W.; Chen, Y. Recent Climate Changes over the Tibetan Plateau and Their Impacts on Energy and Water Cycle: A Review. Glob. Planet. Chang. 2014, 112, 79-91. [CrossRef]

123. Zhou, J.; Wen, J.; Liu, R.; Wang, X.; Xie, Y. Late Spring Soil Moisture Variation over the Tibetan Plateau and Its Influences on the Plateau Summer Monsoon. Int. J. Climatol. 2018, 38, 4597-4609. [CrossRef] 
124. Cottenie, K. Integrating Environmental and Spatial Processes in Ecological Community Dynamics. Ecol. Lett. 2005, 8, 1175-1182. [CrossRef]

125. Spatial Structure and Soil Properties Shape Local Community Structure of Plant-Parasitic Nematodes in Cultivated Olive Trees in Southern Spain. Agric. Ecosyst. Environ. 2020, 287, 106688. [CrossRef]

126. De Goede, R.G.M.; Bongers, T. Nematode Community Structure in Relation to Soil and Vegetation Characteristics. Appl. Soil Ecol. 1994, 1, 29-44. [CrossRef]

127. Deyn, G.B.; Raaijmakers, C.; Zoomer, H.; Berg, M.; Ruiter, P.; Verhoef, H.; Bezemer, T.M.; Putten, W. Soil Invertebrate Fauna Enhances Grassland Succession and Diversity. Nature 2003, 422, 711-713. [CrossRef] [PubMed]

128. Robertson, G.P.; Freckman, D.W. The Spatial Distribution of Nematode Trophic Groups Across a Cultivated Ecosystem. Ecology 1995, 76, 1425-1432. [CrossRef]

129. Rossi, J.-P.; Queneherve, P. Relating Species Density to Environmental Variables in Presence of Spatial Autocorrelation: A Study Case on Soil Nematodes Distribution. Ecography 1998, 21, 117-123. [CrossRef] 